\title{
A Legal Prespective of Right to Nationality and Protection to Stateless Persons in International Law
}

Dr. K. Sangeetha*

Assistant Professor, School of Excellence in Law, Department of International Law, The Tamil Nadu Dr. Ambedkar Law University, Chennai 600028, India

DOI: $10.36348 /$ sijlcj.2019.v02i12.002 $\quad$ | Received: 16.12 .2019 | Accepted: 24.12 .2019 | Published: 30.12 .2019

*Corresponding author: Dr. K. Sangeetha

Abstract

Statelessness is the absence of the right to have a legal connection between Nationality and State. The State of Nationality is an identity to enjoy a 'right to have rights'. Statelessness disrupts the enjoyment of all the rights which are generally perceived or purported to have been granted for all including inter alia the right to work, the right to vote, the right to health, the right to welfare benefits or welfare and a child's right to education. Statelessness precludes people from relocating and increases their chances of arbitrary arrest, confinement or detention with no adequate answers. In short, Statelessness demotes and generates a state of irrelevance among the people with no hope of their condition ever improving, no possibility for a better future for themselves or their posterity. The state of Statelessness dismantles the idea of cohesive human existence in a civilized world. Therefore, Statelessness is a deprivation of a range of rights and benefits that bestow upon individuals Constitutional identity, National security and State protection popularly known as Nationality or Citizenship. Statelessness may be imputed to a catena of causes including Administrative practices, Conflict of Laws, Discrimination, Denationalization, Matrimonial litigation, Non-registration of births, Persecution, Renunciation, Transfer of territories, Re-demarcation of new boundaries, State succession, Terrorism, Climate change and forced displacement and Migration. But its magnitude and scale still remain to be mapped because the problem of Statelessness is a new predicament for International Law and its offshoots. It has emerged as an ordeal for the International Community that has to attend to the plight of 10 million Stateless persons Worldwide. United Nations High Commissioner for Refugees' (UNHCR) mandate is well founded in light of the sheer amount of Stateless persons. Furthermore, there are also at least 1.5 million stateless refugees and around 3.5 million Stateless refugees of Palestinian origin whose problems have posed challenges to the International Law framework. In this paper, an attempt has been made to understand their plights and Human Rights violations against them. Suggestions are made with respect to how to end and ensure the reduction of Statelessness under the architecture of International Law within and beyond the pragmatism of International Relations, Diplomatic narratives and orientations engrossed in occidentalism and orientalism.

Keywords: Right to Nationality, Reduction of Statelessness, International Migration Law.

Copyright @ 2019: This is an open-access article distributed under the terms of the Creative Commons Attribution license which permits unrestricted use, distribution, and reproduction in any medium for non-commercial use (NonCommercial, or CC-BY-NC) provided the original author and source are credited.

\section{INTRODUCTION}

Statelessness is the absence of the right to have a legal connection between Nationality and State. The State of Nationality is an identity to enjoy a 'right to have rights'. Statelessness disrupts the enjoyment of all the rights which are generally perceived or purported to have been granted for all including inter alia the right to work, the right to vote, the right to health, the right to welfare benefits or welfare and a child's right to education. Statelessness precludes people from relocating and increases their chances of arbitrary arrest, confinement or detention with no adequate answers. In short, Statelessness demotes and generates a state of irrelevance among the people with no hope of their condition ever improving, no possibility for a better future for themselves or their posterity.

The state of Statelessness dismantles the idea of cohesive human existence in a civilized world. Therefore, Statelessness is a deprivation of a range of rights and benefits that bestow upon individuals Constitutional identity, National security and State protection popularly known as Nationality or Citizenship. Statelessness may be imputed to a catena of causes including Administrative practices, Conflict of Laws, Discrimination, Denationalization, 
Matrimonial litigation, Non-registration of births, Persecution, Renunciation, Transfer of territories, Redemarcation of new boundaries, State succession, Terrorism, Climate change and forced displacement and Migration. But its magnitude and scale still remain to be mapped because the problem of Statelessness is a new predicament for International Law and its offshoots. It has emerged as an ordeal for the International Community that has to attend to the plight of 10 million Stateless persons worldwide.

United Nations High Commissioner for Refugees' (UNHCR) mandate is well founded in light of the sheer amount of Stateless persons. Furthermore, there are also at least 1.5 million stateless refugees and around 3.5 million Stateless refugees of Palestinian origin whose problems have posed challenges to the International Law framework. In this paper, an attempt has been made to understand their plights and Human Rights violations against them. Suggestions are made with respect to how to end and ensure the reduction of Statelessness under the architecture of International Law within and beyond the pragmatism of International Relations, Diplomatic narratives and orientations engrossed in occidentalism and orientalism [1].

\section{The Right to a Nationality}

The right to a nationality is a fundamental human right. It implies the right of each individual to acquire change and retain a nationality. International human rights law provides that the right of States to decide who their nationals are is not absolute and, in particular, States must comply with their human rights obligations concerning the granting and loss of nationality [2].

\section{Arbitrary Deprivation of Nationality}

The right to retain a nationality corresponds to the prohibition of arbitrary deprivation of nationality. Arbitrary deprivation of nationality, therefore, effectively places the affected persons in a more disadvantaged situation concerning the enjoyment of their human rights because some of these rights may be subjected to lawful limitations that otherwise would not apply, but also because these persons are placed in a situation of increased vulnerability to human rights violations.

\section{International Legal Framework}

\footnotetext{
${ }^{1}$ L.V. Oppenheim, International Law 669 (1955), cited in Rachel Settlage, Note, No Place To Call Home: Stateless Vietnamese Asylum-Seekers In Hong Kong, 12. IMMIGR. L.]. 187, 192 (1997).
}

\section{JACK DONNELLY, UNIVERSAL HUMAN RIGHTS IN THEORY \& PRACTICE 10 (2d Ed. 2003).}

The right to a nationality is recognized in a series of international legal instruments, including the Universal Declaration of Human Rights, the International Convention on the Elimination of All Forms of Racial Discrimination, the International Covenant on Civil and Political Rights, the Convention on the Rights of the Child, the Convention on the Elimination of All Forms of Discrimination against Women, the Convention on the Nationality of Married Women, the Convention on the Rights of Persons with Disabilities and the International Convention on the Protection of the Rights of All Migrant Workers and Members of Their Families. The issue of nationality is also regulated in the Convention on the Reduction of Statelessness, the Convention relating to the Status of Stateless Persons and the Convention relating to the Status of Refugees [3].

An explicit and general prohibition of arbitrary deprivation of nationality can be found in numerous international instruments. In particular, it is worth noting that article 15 of the Universal Declaration of Human Rights explicitly provides that no one should be arbitrarily deprived of his or her nationality. The General Assembly, in its resolution 50/152, also recognized the fundamental nature of the prohibition of arbitrary deprivation of nationality.

Statelessness

The 1954 Convention relating to the Status of Stateless Persons defines "stateless person" as "a person who is not considered as a national by any State under the operation of its law." The exact number of stateless people is not known, but UNHCR estimates that there are at least 10 million globally. In addition to violations of their right to a nationality, stateless persons are subject to several other human rights violations. States shall introduce safeguards to prevent statelessness by granting their nationality to persons who would otherwise be stateless and are either born in their territory or are born abroad to one of their nationals. States shall also prevent statelessness upon loss or deprivation of nationality [4].

\section{The Right to a Nationality and the Human Rights Council}

The Human Right Council has addressed the enjoyment of the right to a nationality and the

${ }^{3}$ Carol A. Batchelor, Statelessness and the Problem of Resolving Nationality Status, 10 INT'L). REFUGEE L. 156, 172 (1998).

${ }^{4}$ UNITED NATIONS HIGH COMMISSIONER FOR REFUGEES (UNHCR), INFORMATION AND ACCESSION PACKAGE: THE 1954 CONVENTION RELATING TO THE STATUS OF STATELESS PERSONS AND THE 1961 CONVENTION ON THE REDUCTION OF STATELESSNESS (rev. ed. 1999). 
avoidance of statelessness in several resolutions on "Human rights and arbitrary deprivation of nationality":

\section{RESPONSES OF THE INTERNATIONAL COMMUNITY TO TACKLE STATELESSNESS}

In Public International Law, after the creation of the United Nations (1945), two parallel approaches have been formulated to tackle this negative phenomenon. The first focuses on identifying the magnitude of the problem; preventing statelessness pro future and reducing the existing number of stateless persons as much as possible. This attempt is marked principally by the 1961 UN Convention on the Reduction of Statelessness on the universal level; and with some other not so comprehensive treaties on the regional (European) level. This specific legal framework is embedded in the general human rights law and completed by provisions relating to the right to nationality.

Nevertheless, despite all these efforts, it is a matter of fact that the number of Stateless persons will never reach zero. Therefore a new, autonomous Legal status has been created by virtue of the 1954 Convention relating to the Status of Stateless Persons, aiming at providing an appropriate standard of international protection, a status comparable to other forms of international protection such as refugee status. In today's International Law, it is still the $1965 \mathrm{New}$ York Convention alone, almost sixty years later, under which stateless people enjoy specific International Legal Protection, containing the basic rules and rights determining their Legal status [5].

Nationality is a legal bond between a person and a State. Nationality provides people with a sense of identity but, more importantly, enables them to exercise a wide range of rights. The lack of any nationality, statelessness, can therefore be harmful, in some cases devastating to the lives of the individuals concerned.

Despite International recognition of the right to a nationality, new cases of statelessness have continued to arise. Tackling statelessness still poses a major challenge in the $21 \mathrm{st}$ century. There are at least 10 million stateless people around the world today. While

\footnotetext{
${ }^{5}$ The ICCPR states that "[t]he right of men and women of marriageable age to marry and to found a family shall be recognized." ICCPR, supra note 6, art. 23, '[] 2. In its General Comment 19, the Human Rights Committee stated that: The right to found a family implies, in principle, the possibility to procreate and live together ... (and] the possibility to live together implies the adoption of appropriate measures, both at the internal level and as the case may be, in cooperation with other States, to ensure the unity or reunification of families, particularly when their members are separated for political, economic or similar reasons.
}

some stateless persons are refugees at the same time, most are not. Stateless persons who are also refugees are entitled to the international protection afforded by the 1951 Convention relating to the Status of Refugees ("1951 Convention"). To address the protection problems faced by stateless persons, in particular those who are not refugees, the international community adopted the 1954 Convention relating to the Status of Stateless Persons ("1954 Convention"). This treaty aims to regulate the status of stateless persons and to ensure the widest possible enjoyment of their human rights. The Convention complements provisions of International human rights treaties. A growing number of States are turning to the 1954 Convention as a framework for the protection of stateless persons This reflects understanding that the 1954 Convention relating to the Status of Stateless Persons is the only legal instrument that formally establishes the international legal status of "stateless persons". The Convention also addresses many practical concerns relating to the protection of stateless persons such as access to travel documents that are not dealt with elsewhere in International law [6].

While the 1954 Convention had only 65 States Parties on 1 January 2011, more States have been acknowledging that it is a central component of the international regime for enhancing the protection of the rights of stateless persons. Twenty-three States pledged to accede to the Convention at the Ministerial Event organized by the UNHCR in December 2011. By the end of January 2014, 80 States were parties.

The 1954 Convention recognises the International legal status of "Stateless persons". Article 1 establishes the definition of a stateless person in international law: someone "who is not considered as a national by any State under the operation of its law". This definition is now also recognised to be customary international law. Establishing whether or not a person is considered as a national under the operation of a country's law, requires a careful analysis of how the State applies its nationality laws in practice. Persons who satisfy the definition are entitled to certain rights and must comply with certain duties contained in the 1954 Convention. The Convention does not cover so called de facto stateless persons for whom no universally accepted definition exists in international law. However, de facto stateless persons are entitled to protection under international human rights law. Stateless refugees are covered by the 1951 Convention relating to the Status of Refugees and should be treated in accordance with international refugee law.

The 1954 Convention is based on a core principle: no stateless person should be treated worse

\footnotetext{
${ }^{6}$ Sri Lanka Grants Citizenship to More than 168,000 Stateless Tamils, BBC WORLDWIDE MONITORING, 7 Oct. 2003.
} 
than any foreigner who possesses a nationality. In addition, the Convention acknowledges that stateless persons are more vulnerable than other foreigners. It therefore provides for a series of special measures for stateless persons. The 1954 Convention guarantees stateless persons a right to administrative assistance (Article 25), a right to identity and travel documents (Articles 27 and 28) and exempts them from reciprocity requirements (Article 7). These tailor- made provisions are designed to deal with the particular difficulties faced by stateless persons due to their lack of any nationality, for instance by providing for a mutually-recognised travel document for stateless persons to function in lieu of a passport. These matters are not regulated elsewhere in international law and are among the core legal benefits for stateless persons under the 1954 Convention.

Considering the plight of stateless people, the Convention stipulates that they must be treated like nationals of the State with regard to certain rights such as freedom of religion or elementary education. It must be stressed that the Convention pursues a nuanced approach, specifying that some guarantees apply to all stateless people while others are reserved to stateless persons lawfully present or lawfully staying in the territory. The 1954 Convention thus echoes human rights standards contained in other international instruments and provides guidance on how such standards are to be implemented for stateless persons. As set out in Article 2 of the 1954 Convention, all stateless persons have the duty to obey the laws and regulations of the country in which they find themselves. It is important to note that the enjoyment of the rights guaranteed under the 1954 Convention does not equate to possession of a nationality. This is why the 1954 Convention calls upon States to facilitate the naturalization (Article 32) of stateless persons. Once they acquire a nationality, stateless persons are no longer stateless: their plight has come to an end.

The 1954 Convention does not prescribe a particular procedure for the determination of whether a person is a stateless person. However, national status determination procedures should offer certain core elements, which are necessary for fair and efficient decision-making in keeping with international protection standards. These include designating a central authority with the relevant knowledge and expertise to assess applications, procedural safeguards and guarantees at all stages of the process and possibility for appeal or review. UNHCR has been tasked to assist States to establish such procedures.

UNHCR assists States to implement the 1954 Convention by offering technical advice regarding legislation and operational support to promote the implementation of determination procedures and measures to ensure the rights foreseen in the Convention. UNHCR's Executive Committee has specifically requested the Office to "actively disseminate information and, where appropriate, train government counterparts on appropriate mechanisms for identifying, recording, and granting a status to stateless persons" (see UNHCR's Executive Committee Conclusion 106 on Identification, Prevention and Reduction of Statelessness and Protection of Stateless Persons, 2006, for more information). All human beings have the right to a nationality and whenever the anomaly of statelessness arises, the focus should be on preventing and reducing it.

Protection of stateless persons under the 1954 Convention relating to the Status of Stateless Persons should thus be seen as temporary response while avenues for the acquisition of a nationality are explored. The reduction of statelessness through acquisition of nationality remains the ultimate goal. The 1961 Convention on the Reduction of Statelessness provides States with tools for avoiding and resolving cases of statelessness.

However, States Parties to the 1961 Convention should still consider acceding to the 1954 Convention to ensure that protective measures are in place when they nevertheless encounter cases of statelessness. Acceding to both the 1954 and 1961 Statelessness Conventions is a key step to equip States to tackle the full range of statelessness problems. More detailed information about the 1961 Convention can be found in Preventing and Reducing Statelessness - The 1961 Convention on the Reduction of Statelessness (UNHCR, 2014).[7].

Although the definition in Article 1(1) is formulated in the negative ("not considered to be a national by any State"), an enquiry into whether someone is stateless is limited to the States with which a person enjoys a relevant link, in particular by birth on the territory, descent, marriage, or habitual residence. In some cases this may limit the scope of investigation to only one State (or indeed to an entity which is not a State).

The definition of "State" in Article 1(1) is informed by how the term has generally evolved in international law. The criteria in the 1933 Montevideo Convention on the Rights and Duties of States remain pertinent in this regard. According to that Convention, a State is constituted when an entity has a permanent population, defined territory, effective government and capacity to enter into relations with other States. Other factors of statehood that have subsequently emerged in international legal discourse include the effectiveness of

\footnotetext{
7 Jeffrey L. Blackman, State Successions and Statelessness: The Emerging Right to an Effective Nationality under International Law, 19 MICH). INT'L L. 1141 (1998).
} 
the entity in question, the right of self-determination, the prohibition on the use of force and the consent of the State which previously exercised control over the territory in question.

The reference to "law" in Article 1(1) should be read broadly to encompass not just legislation, but also ministerial decrees, regulations, orders, judicial case law (in countries with a tradition of precedent) and, where appropriate, customary practice. Establishing whether an individual is not considered as a national under the operation of its law requires a careful analysis of how a State applies its nationality laws in an individual's case in practice and any review/appeal decisions that may have had an impact on the individual's status. This is a mixed question of fact and law. Applying this approach of examining an individual's position in practice may lead to a different conclusion than one derived from a purely objective analysis of the application of nationality laws of a country to an individual's case. A State may not in practice follow the letter of the law, even going so far as to ignore its substance. The reference to "law" in the definition of statelessness in Article 1(1) therefore covers situations where the written law is substantially modified when it comes to its implementation in practice.

\section{Citizenship Amendment Bill - December 9, 2019}

The Minister of Home Affairs introduced the Citizenship (Amendment) Bill, 2019 on December 9th 2019 in Lok Sabha. It is scheduled to be taken up for discussion and passing by the House. The Bill amends the Citizenship Act, 1955, and seeks to make foreign illegal migrants of certain religious communities coming from Afghanistan, Bangladesh, and Pakistan eligible for Indian Citizenship. The criteria for determining Citizenship in India, discuss how the Bill proposes to change the criteria, and highlight other key changes proposed in the Bill.

In India, Citizenship is regulated by the Citizenship Act, 1955. The Act specifies that citizenship may be acquired in India through five methods by Birth in India, by Descent, through Registration, by Naturalisation (extended residence in India), and by Incorporation of territory into India. An illegal migrant is prohibited from acquiring Indian Citizenship. An illegal immigrant is a foreigner who either enters India illegally, i.e., without valid travel documents, like a visa and passport, or enters India legally, but stays beyond the time period permitted in their travel documents. An illegal migrant can be prosecuted in India, and deported or imprisoned.

In September 2015 and July 2016, the Central Government exempted certain groups of illegal migrants from being imprisoned or deported. These are illegal migrants who came into India from Afghanistan, Bangladesh, or Pakistan on or before December 31,
2014, and belong to the Hindu, Sikh, Buddhist, Jain, Parsi, or Christian religious communities. The Bill proposes that the specified class of illegal migrants from the three Countries will not be treated as illegal migrants, making them eligible for Citizenship. On acquiring Citizenship, such migrants shall be deemed to be Indian Citizens from the date of their entry into India and all legal proceedings regarding their status as illegal migrants or their Citizenship will be closed. The Bill does not explain how these three neighbouring Countries were grouped when other neighbouring Countries were not included. The Bill does not clearly explain the selection and inclusion of certain religious communities leaving out or exempting the other religious communities that exists in the Society.

The Act allows a person to apply for Citizenship by Naturalisation, if the person meets certain qualifications. One of the qualifications is that the person must have resided in India or been in Central Government service for the last 12 months and at least 11 years of the preceding 14 years. For the specified class of illegal migrants, the number of years of residency has been relaxed from 11 years to five years.

The Bill clarifies that the proposed amendments on Citizenship to the specified class of illegal migrants will not apply to certain areas. These are: (i) the tribal areas of Assam, Meghalaya, Mizoram, and Tripura, as included in the Sixth Schedule to the Constitution, and (ii) the states regulated by the "Inner Line" permit under the Bengal Eastern Frontier Regulations 1873. These Sixth Schedule tribal areas include Karbi Anglong (in Assam), Garo Hills (in Meghalaya), Chakma District (in Mizoram), and Tripura Tribal Areas District. Further, the Inner Line Permit regulates visit of all persons, including Indian citizens, to Arunachal Pradesh, Mizoram, and Nagaland.

The Bill makes only certain illegal migrants eligible for citizenship. These are persons belonging to the six specified religious communities, from the three specified countries, who entered India on or before December 31, 2014, and do not reside in the Sixth Schedule areas or in the states regulated by the Inner Line Permit states. This implies that all other illegal migrants will not be able to claim the benefit of citizenship conferred by the Bill, and may continue to be prosecuted as illegal migrants. Any provision which distinguishes between two groups may violate the standard of equality guaranteed under Article 14 of the Constitution, unless one can show a reasonable rationale for doing so. The Bill provides differential treatment to illegal migrants on the basis of (a) their country of origin, (b) religion, (c) date of entry into India, and (d) place of residence in India. The question is whether these factors serve a reasonable purpose to justify the differential treatment. We examine this below. 
The Bill classifies migrants based on their Country of origin to include only Afghanistan, Pakistan and Bangladesh. While the Statement of Objects and Reasons (SoR) in the Bill reasons that millions of Citizens of undivided India were living in Pakistan and Bangladesh, no reason has been provided to explain the inclusion of Afghanistan. The SoR also states that these countries have a state religion, which has resulted in religious persecution of minority groups. However, there are other Countries which may fit this qualification. For instance, two of India's neighboring Countries, Sri Lanka (Buddhist state religion) and Myanmar (primacy to Buddhism), have had a history of persecution of Tamil Eelams (a linguistic minority in Sri Lanka), and the Rohingya Muslims, respectively.

Further, there are other religious minorities from Pakistan, Afghanistan and Bangladesh, such as the Ahmadiyya Muslims in Pakistan (considered nonMuslims in that country), and atheists in Bangladesh who have faced religious persecution and may have illegally migrated to India. Given that the objective of the Bill is to provide citizenship to migrants escaping from religious persecution, it is not clear why illegal migrants belonging to other neighbouring Countries, or belonging to Religious minorities from these three specified Countries, have been excluded from the Bill.

The Bill also creates further differentiation between the specified class of illegal migrants based on when they entered India (before or after December 31, 2014), and where they live in India (provisions not applicable to Sixth Schedule and Inner Line Permit areas). However, the reasons provided to explain the distinction is unclear. Note that certain restrictions apply to persons (both citizens and foreigners) in the Sixth Schedule areas and in the states regulated by the Inner Line Permit. Once an illegal migrant residing in these areas acquires citizenship, he would be subject to the same restrictions in these areas, as are applicable to other Indian citizens. Therefore, it is unclear why the Bill excludes illegal migrants residing in these areas.

The Bill also amends the provisions on registration of Overseas Citizens of India (OCI). OCI cardholders are foreigners who are persons of Indian origin. For example, they may have been former Indian citizens, or children of current Indian citizens. An OCI enjoys benefits such as the right to travel to India without a visa, or to work and study here. At present, the Government may cancel a person's OCI registration on various grounds specified in the Act. In case of a cancellation, an OCI residing in India may be required to leave the country. The Bill adds another ground for cancelling OCI registration violation of any law notified by the central government. However, the Bill does not provide any guidance on the nature of laws which the central government may notify. The Supreme Court has noted that this guidance is necessary to set limits on the authority's powers and to avoid any arbitrariness in exercise of powers. Therefore, the powers given to the Government under the Bill may go beyond the permissible limits of valid delegation.

\section{CONCLUSION}

One way to ensure that stateless persons realize their right to a nationality, as enunciated in Article 15 of the Universal Declaration, is through the doctrine of the genuine and effective link. According to this doctrine, a person should be eligible to receive citizenship from states with which she or he has a substantial connection or a genuine and effective link. At the very least, a person should be eligible for the citizenship of the country with which she or he has the closest link or connection. A substantial link or connection to a state can be forged by, for example, long-term habitation in a state without a more substantial link to another state, descent from a state's citizen, birth within a state's territory, or citizenship in a country's former federal state.

The doctrine of the genuine and effective link is a viable solution to the problem of statelessness because it is generally "not difficult to determine to which state an individual has a genuine effective link for purposes of nationality decisions difficulties in preventing or reducing statelessness often occur as a result of legislative, judicial, administrative, and political decisions which fail to recognize basic principles of international law with respect to nationality. Indeed, there is hardly a person without a genuine and substantial link to a state. As a practical matter, however, a sovereign state has the right to determine who receives its citizenship. This right, however, should be congruent with relevant international standards and laws. At a minimum, these standards prohibit states from rendering their citizens stateless, oblige states to respect the human rights of stateless persons, and obligate states to grant citizenship to all children born within state borders. 